Biol. Neonat. 1969;14:I-IV

\title{
Contents, Vol. 14, 1969
}

\section{Index}

Acosta-Ferreira, W.: vide Morelli, A. C

Adam, P.A.J.; Kornhauser, D.; Link, D. and Schwartz, R.: Relationship of Insulin Secretion Rate to Blood Glucose Concentration in Newborn and Adult Dogs 194

Alexander, G.: The Effect of Adrenaline and Noradrenaline on Metabolic Rate in Young Lambs 97

Alexander, Pauline D.; Britton, H. G.; Cohen, N. M. and Nixon, D. A.: Plasma

Concentrations of Insulin, Glucose, Free Fatty Acids and Ketone Bodies in the Foetal and Newborn Sheep and the Response to a Glucose Load Before and After Birth 178

Alexander, Pauline D. and Nixon, D.A.: Effect of Parathyroid Extract in Foetal Sheep 117

Alexiou, D.: vide Papadatos, C

Amiel-Tison, Claudine : Cerebral Damage in Full-Term New-Born Aetiological

Factors, Neonatal Status and Long-Term Follow-Up 234

Assche, F.A. Van; Gepts, E. and Gasparo, M. De: The Endocrine Pancreas in

Anencephalics. A Histological, Histochemical and Biological Study

Assche, F. A. Van : Histoenzymatical Study of the Fetal Pancreas in Late Pregnancy 19

Avery, Mary E.: vide Spear, G. S

Barnett, R.: vide Cassady, G

Bazsó, J.: A Comparison of Normal Foetal Growth and its Variation by the Birth Weight Percentiles from Different Populations

Berezin, A.: Histochemical Study of the Hyaline Membrane of Newborn Infants and of that Produced in Guinea Pigs 90

Bergman, R. A.: vide Spear, G. S

Bessman, S.P.; Wapnir, R.A.; Pankratz, H.S. and Plantholt, Barbara, A.:

Maternal Phenylalanine Deprivation in the Rat. Enzymatic and Cellular Liver

Changes in the Offspring 107

Britton, H. G.: vide Alexander, Pauline, D

Campbell, D.: vide Dubignon, J. M

Cassady, G. and Barnett, R.: Acid-Base and Gas Tension Studies of the Amniotic

Fluid in Human Gestation 251

Cohen, N. M.: vide Alexander, Pauline D

Demus-Oole, Annmarie and Swierczewski, Elisabeth: Glutathione Peroxidase

in Rat Liver During Development. I. Localization and Characterization of

the Subcellular Liver Fractions of Newborn and Adult Rat 211

Demus-Oole, Annmarie and Swierczewski, Elisabeth: Glutathione Peroxidase

in Rat Liver During Development. II. Changes in Glutathione Peroxidase 
During Post-Natal Development of Normal and Hypotrophic Rats 219

Devriendt, A.: vide Jansen, F. H

Dobbs, C.: vide Robertson, A.F

Dubignon, J.M.; Campbell, D. and Partington, M,W.: The Development of

Non-Nutritive Sucking in Premature Infants 270

Doszpod, J.: vide Mestyán, J

Edwards, A.V. and Silver, Marian: The Effect of Asphyxia on the Plasma

Glucose Concentration in New-Born Calves

1

Eitzman, D. V.: vide Vaughan, O

Fekete, M.: vide Mestyán, J

Gasparo, M. De : vide Assche, F. A. Van

Gati, I.: vide Mestyán, J

Gepts, W.: vide Assche, F. A. Van ,

Glass, L.; Silverman, W.A. and Sinclair, J.C.: Relationship of Thermal En

vironment and Caloric Intake to Growth and Resting Metabolism in the

Late Neonatal Period 324

Hahn, P.: vide Novak, $M$

Heirwegh, K. P. M.: vide Jansen, F. H

Heirwegh, K.P. M.; Meuwissen, J.A.T.P. and Jansen, F.H.: On the Quantita-

tion and Analysis of Bile Pigments in Amniotic Fluid

74

Heringová, A.; Koldovský, O.; Yaffe, S. J.; Jirsová, V. and Uher, J.: Sulfatase

Activity in Placenta, Liver and Small Intestine of Human Fetuses 265

Hodr, J.: vide Kittrich, M

Hommes, F. A. and Richters, A. R.: Mechanism of Oxidation of Cytoplasmic

Reduced Nicotinamide Adenine Dinucleotides in the Developing Rat Liver 359

Hommes, F. A.; Wilmink, C. W. and Richters, A.: The Development of Thyroid

Function in the Rat 69

Horská, S.; Sofrová, D. and Stembera, Z.K.: Variation of the ATP Content of

Foetal Blood after Hypoxia in Childbirth 279

Imhof, S.: vide Mestyán, J

Jansen, F. H.: vide Heirwegh, K. P. M

Jansen, F. H.; Malvaux, P.; Heirwegh, K. P. M. and Devriendt, A.: Congenital

Non-Hemolytic Jaundice: Crigler-Najjar Syndrome 53

Járai, I.: vide Mestyán, J

Jirsova, V.: vide Heringová, A

Kittrich, M.; Stembera, Z. and Hodr, J.: Changes of Pyruvic Acid Concentra

tions in Amniotic Fluid During Labour and Relations to Their Concentra

tions in Fetal and Maternal Blood 226

Koldovský, O.: vide Heringová, A

Kornhauser, D.: vide Adam, P. A. J

Lajos, L.: vide Mestyán, J

Link, D.: vide Adam, P. A. J

Malvaux, P.: vide Jansen, F. H

Melichar, V.: vide Novak, $M$

Mendris, J.: vide Papadatos, C 
Mestyán, J.; Fekete, M.; Járai, I.; Sulyok, E.; Imhof, S. and Soltész, G.: The Postnatal Changes in the Circulating Free Amino Acid Pool in the Newborn Infant. II. The Plasma Amino Acid Ratio in Intrauterine Malnutrition ('Small for Dates' Full-Term, Preterm and Twin Infants) 164 Mestyán, J.; Fekete, M.; Soltész, G.; Lajos, L.; Gati, I.; Preisz, J. and Doszpod,J. : The Postnatal Changes in the Circulating Free Amino Acid Pool in the Newborn Infant. I. The Plasma Amino Acid Ratio on Normal FullTerm and Preterm Infants 153 Meuwissen, J.A.T.P.: vide Heirwegh, K.P.M Morelli, A. C.; Acosta-Ferreira, W.; Pollini, H. and Pino, Maria Clara Del : Plasmatic Protein Separation by Gel Filtration Chromatography and Reproduction in vitro of Fibres Similar to the Hyaline Membrane of the Newborn 142

Msuya, P. M. and Schepartz, B.: Development of Tyrosine-Metabolizing

Enzymes in Rat Liver During the First Day after Birth 317

Nachman, R.: vide Spear, G. S

Nixon, D. A.: vide Alexander, Pauline D

Novak, M.; Hahn, P. and Melichar, V.: Postnatal Development of Human

Adipose Tissue, Oxygen Consumption and Oxidation of Fatty Acids .... 203

Pankratz, H. S.: vide Bessman, S. P

Papadatos, C.; Papaevangelou, G.; Alexiou, D. and Mendris, J.: Immunoglo-

bulin Levels and Gestational Age 365

Papaevangelou, G.: vide Papadatos, C

Partington, M. W.: vide Dubignon, J. M

Pino, Maria Clara Del : vide Morelli, A. C

Plantholt, Barbara, A.: vide Bessman, S. P

Pollini, H.: vide Morelli, A. C

Preisz, J.: vide Mestyán, J

Pribylová, H. and Znamenácek, K.: Oxygen Consumption and Other Regulative

Mechanisms of Energy Metabolism in Pathological States of the Newborn 133

Richters, A. R.: vide Hommes, F. A

Robertson, B.: The Incidence of Structure of Bronchopulmonary Arteries in Infancy and Early Childhood 62

Robertson, A.F.; Sprecher, H. and Dobbs, C.: Metabolism of Cholesterol Esters in the Human Placenta 32

Robertson, A.F.; Sprecher, H.W. and Wilcox, Justina P.: Total Lipid Fatty

Acid Patterns of Umbilical Cord Blood in Intrauterine Growth Failure .. 28

Schepartz, B.: vide Msuya, P. M

Schwartz, R.: vide Adam, P. A. J

Shanklin, D.R. and Sotelo-Avila, C.: In situ Tumors in Fetuses, Newborns

and Young Infants (with colour plates I and II) 286

Silverman, W. A.: vide Glass, L

Silver, Marian: vide Edwards, A.V

Sinclair, J. C.: vide Glass, L

Sofrová, D.: vide Horská, S

Soltész, G.: vide Mestyán, J

Sotelo-Avila, C.: vide Shanklin, D.R 
Spear, G.S.; Vaeusorn, O.; Avery, Mary E.; Nachman, R.; Wolfsdorf, J. and Bergman, R. A.: Inclusions in Terminal Air Spaces of Fetal and Neo natal Human Lung 344

Spencer, R. P.: Radiographically Determined Sternal Ossification. An Approach to Skeletal Maturity 341

Sprecher, H.W.: vide Robertson, A. F

Stembera, Z. K.: vide Horská, S.

Stembera, Z.: vide Kittrich, M

Sulyok, E.: vide Mestyán, J

Sweet, A. Y.: The Effect of Bradykinin on the Course of Respiratory Distress

Syndrome 8

Swierczewski, Elisabeth: vide Demus-Oole, Annmarie

Uher, J.: vide Heringová, A

Vaeusorn, O.: vide Spear, G. S

Vaughan, O. and Eitzman, D. V.: Hypoxia and Lactate in the Newborn Puppy 42

Wapnir, R. A.: vide Bessman, S. P

Wilcox, Justina P.: vide Robertson, A. F

Wilmink, C. W.: vide Hommes, F. A

Wolfsdorf, J.: vide Spear, G. S

Yaffe, S. J.: vide Heringová, A

Znamenácek, K.: vide Pribylová

Buchbesprechungen-Book Reviews-Livres Nouveaux 131, 264

Varia 264

All rights, including that of translation into other languages, reserved.

Photomechanic reproduction (photocopy, microcopy) of this volume or parts thereof without special permission of the publishers is prohibited

(C)

Copyright 1969 by S. Karger AG, Basel

Printed in Switzerland by Buchdruckerei Fritz Pochon-Jent AG, Bern

Cliches: Aberegg-Steiner, Bern 